\title{
Water quality and health risk assessment of trace elements contamination in Ghodaghodi Lake, Sudurpaschim Province, Nepal
}

\author{
Ramesh Raj Pant ${ }^{1}$, Gita Pathak ${ }^{1}$, Khadka Bahadur Pal ${ }^{2,}$, , Kiran Bishwakarma ${ }^{3}$, Lal B \\ Thapa ${ }^{4}$, Yam Prasad Dhital ${ }^{5}$, Youb Raj Bhatta ${ }^{1}$, Ganesh Raj Joshi, Kedar Rijal ${ }^{1}$

\begin{abstract}
${ }^{1}$ Central Department of Environmental Science, Institute of Science and Technology, Tribhuvan University, Nepal
${ }^{2}$ Department of Chemistry, Tri-Chandra Multiple Campus, Tribhuvan University, Kathmandu, Nepal

${ }^{3}$ Institute of Tibetan Plateau Research, Chinese Academy of Sciences, Beijing, China

${ }^{4}$ Central Department of Botany, Institute of Science and Technology, Tribhuvan University, Nepal

${ }^{5}$ Institute of Eco-Chongming, Faculty of Earth Sciences, East China Normal University, Shanghai, China

${ }^{6}$ United Nations Centre for Regional Development, Nagoya, Japan
\end{abstract}

(Received: 16 April 2021; Revised: 02 July 2021; Accepted: 03 July 2021)

\begin{abstract}
The contamination of trace elements (TEs) in freshwater sources has become an alarming issue globally. This study evaluates the contamination level of TEs, their spatial distributions, and the health risks in the Ghodaghodi Lake complex, Nepal. Altogether, ten water samples were collected, and As, Ba, Cd, Co, Cr, $\mathrm{Cs}, \mathrm{Cu}, \mathrm{Li}, \mathrm{Mn}, \mathrm{Ni}, \mathrm{Pb}, \mathrm{Rb}, \mathrm{Sc}, \mathrm{Sr}, \mathrm{Ti}, \mathrm{TI}, \mathrm{V}, \mathrm{Y}$, and $\mathrm{Zn}$ were determined by inductively coupled plasma mass spectrometry. The results revealed that $\mathrm{Sr}, \mathrm{Zn}, \mathrm{Cu}, \mathrm{As}, \mathrm{Sc}$, and $\mathrm{Rb}$ were dominated TEs, contributing to the contamination. The principal component analysis and correlation matrices demonstrated both the geogenic and anthropic origin of the TEs in the lake. The water quality index (WQI=10.08) and hazard indices $<1$ exhibited that the TEs pose a low risk to human health and, hence the water of the lake was suitable for drinking purposes. However, exposure risk assessment results suggested that children are relatively more vulnerable compared to adults. The outcome of this study will provide new insights to local people and the concerned authorities for the sustainable management of Ramsar listed Ghodaghodi Lake complex.
\end{abstract}

Keywords: Ghodaghodi Lake, health risk assessment, Nepal, trace elements, water quality

\section{Introduction}

Freshwater resources are indispensable for all living organisms including human beings (Huang et al., 2009). The freshwater lakes are the major sources of drinking water and maintain the ecological balance that supports many life forms. However, the contamination of these resources is one of the major threats to public and ecological health worldwide (Pant et al., 2020a). Among the various contaminants, trace elements (TEs) are the most toxic and persistent that can impact the aquatic ecosystems through the process of bio-accumulation and bio-magnification (Shah et al., 2012; Xie et al., 2016). In addition, the TEs are transported to the standing (lentic) water bodies through streams, rock weathering, erosion and precipitation. The ongoing retreat of mountain glaciers under the changing scenarios of global climate, extensive land use/cover changes, excessive use of agro-fertilizers and pesticides, industrial and urban sewage discharge, and commercial and domestic sewages are some of the major sources of toxic TEs to the freshwater lakes. Meanwhile, lakes are less dynamic and readily contaminated by the toxic TEs, and thus, are a matter of concern to public health hazards thereafter getting scienti- fic attention. The major TEs contamination in lake water bodies, including Arsenic (As), Barium (Ba), Cadmium (Cd), Cobalt (Co), Chromium (Cr), Cesium (Cs), Copper (Cu), Lithium (Li), Manganese (Mn), Nickel (Ni), Lead (Pb), Rubidium (Rb), Scandium (Sc), Strontium (Sr), Titanium (Ti), Thallium (Tl), Vanadium (V), Yttrium (Y), and Zinc $(\mathrm{Zn})$, has become an alarming issue in many developing countries over the past few decades and Nepal is not the exception (Jehan et al., 2020; Pant et al., 2021a). Some of these elements are carcinogenic (e.g., $\mathrm{As}, \mathrm{Pb}, \mathrm{Cr}$, and $\mathrm{Cd}$ ) and directly affect human health and damage the organs like the liver, kidney, digestive, nervous, and blood circulation systems (Huang et al., 2009). Additionally, some of the health effects caused by these elements include peripheral neuropathy, skin, lung and bladder cancer, tubular dysfunction, neurodevelopment effects, cardiovascular diseases, hypertension, infertility, and adverse pregnancy (WHO, 2011).

Explicitly, $\mathrm{Pb}$ damages the peripheral nervous system, whereas As affects the central nervous system and they are

*Corresponding author: Khadka.pal@gmail.com

${ }^{6}$ Disclaimer: This research is not related to the United Nations and the views expressed herein are those of the authors only and do not necessarily reflect the views of the United Nations. 
responsible for the loss of weight, loss of appetite, and gastrointestinal disorders. Similarly, Ba can cause vomiting, abdominal pain, difficulties in breathing, irregularity in blood circulation, and muscle weakness (Li \& Zhang, 2010). Owing to the potential risk of the TEs mentioned above, various multivariate statistical approaches such as correlation matrix (CM), cluster analysis (CA), and factor/principal component analysis (FA/PCA) are widely used to assess the sources, concentrations, and potential risks posed by the elements to human and ecological health in recent years (Dong et al., 2015; Pant et al., 2018).

Freshwater is one of the prime resources in the Himalayan region which are not only the means of livelihoods support but also a key indicator for ecological sustainability in the entire region (Dong et al., 2015). However, some recent studies have reported that these indispensable resources are being contaminated by various pollutants including TEs (Adhikari et al., 2020; Bishwakarma et al., 2019; Pal et al., 2021; Pant et al., 2020b) . In addition, in the central Himalayas, particularly in Nepal, the freshwater lakes are situated at different ecological regions such as the Koshi Tappu Ramsar area in Sunsari (< 100 masl) and Tilicho Lake in Manang (>4900 masl) are under pressure due to various natural and anthropic factors. The lakes located in the high Himalayas have experienced limited direct anthropic stresses; however, these are susceptible to the impacts of climate change, long-range transport of pollutants, and geogenic weathering. However, there are a limited number of scientific studies available on the lake water hydrochemistry from Nepal Hiamalayas. For instance, Sharma et al. (2015) studied mercury $(\mathrm{Hg})$ contaminations in the two Ramsar listed lakes i.e., the Phewa Lake and the Gosainkunda Lake. They found potential threats of the TEs to these lakes from geogenic, anthropic, and long-range transport of the pollutants. On the other hand, the lakes and other freshwater ecosystems located in the Terai and Hilly regions are experienced high anthropic pressure such as agricultural runoff, domestic and urban wastes (Niraula, 2012; Rupakheti et al., 2017). However, there are very few published literature on the TEs from the lowland region of Nepal.

Ghodaghodi lake complex is one of the Ramsar listed lakes situated in the low-land Terai region of Sudurpaschim Province, Nepal. It is a natural freshwater ecosystem, which is inter-connected with swamps, marshes, and meadows. Despite providing various ecosystem services, the lake faces threats from anthropic activities and natural flash floods especially during the rainy season. In addition, religious and touristic activities also add the chemical pollutants into the lake (Bhatta et al. 2019). This lake has not received enough scientific attention regarding chemical contaminations including TEs and associated human health impacts. Thus, the main objective of this study is to determine the surface water quality of the lake and explore the sources of dissolved TEs including associated health risks. The study could provide an insight on the contaminations of TEs and their potential health risks and contribute to develop appropriate policy measures associated with the water quality management in the Himalayas.

\section{Materials and Methods \\ Study area}

The Ghodaghodi Lake complex (28 $41^{\prime} 03^{\prime \prime} \mathrm{N}$ and $\left.80^{\circ} 56^{\prime} 43^{\prime \prime} \mathrm{E}\right)$ is situated at an elevation of 205 masl, a Ramsar listed lake. It is located in the Kailali district of Sudurpaschim Province, Nepal. The lake complex covers an area of 2563 ha with 14 large and small oxbow lakes associated with marshes, swamps, streams, and springs (Fig. 1). The lake is rich in aquatic macrophytes, fishes, birds, reptiles, and mammals (Lamsal et al., 2014). The persisting anthropic activities like excessive harvesting, poaching, habitat destruction, population pressure, forest fragmentation, siltation, excessive use of fertilizer and pesticide seepage have threatened the existing ecological conditions in the lake (Acharya et al., 2020; Pant et al., 2021c; Tripathee et al., 2016; Xiao et al., 2014).

The Ghodaghodi Lake basin has a tropical monsoon type of climate with distinct seasonality. The mean annual rainfall ranges from $1630 \mathrm{~mm}$ to $1705 \mathrm{~mm}$. About $80 \%$ of the total annual rainfall occurs during the monsoon season from June to September in the lake basin. The average monthly maximum temperature ranges from $21{ }^{\circ} \mathrm{C}$ to $38{ }^{\circ} \mathrm{C}$ and a minimum of $6^{\circ} \mathrm{C}$ to $25^{\circ} \mathrm{C}$ (Bhatta et al., 2019).

\section{Sample collection and lab analysis}

For this study, a total of 10 representative water samples were collected from different sites of the Ghodaghodi Lake (Fig. 1). The samples were collected in the winter season (January) in 2018 at a depth of about 10 to $15 \mathrm{~cm}$. Acid-washed $20 \mathrm{~mL}$ ultra-clean high-density polyethylene (HDPE) bottles with a screw cap were used to collect water samples. The samples were filtered through a $0.45 \mu \mathrm{m}$ polypropylene membrane filter and kept in the refrigerator at $4^{\circ} \mathrm{C}$ until further analysis. To avoid the adsorption of TEs on the walls of the bottles, water samples were acidified to $\mathrm{pH}<2$ by using supra pure nitric acid. A total of 19 TEs (As, Ba, Cd, Co, Cr, Cs, Cu, Li, $\mathrm{Mn}, \mathrm{Ni}, \mathrm{Pb}, \mathrm{Rb}, \mathrm{Sc}, \mathrm{Sr}, \mathrm{Ti}, \mathrm{Tl}, \mathrm{V}, \mathrm{Y}$, and $\mathrm{Zn}$ ) were analyzed using inductively coupled plasma-mass spectrometry (ICP-MS, X-7 Thermo 141 Elemental) at Institute of Tibetan Plateau Research, Chinese Academy of Sciences (ITP-CAS), Beijing, China. The accuracy of the analytical protocol was ascertained by performing the triplicate measurements of the externally certified reference solution, showing the analytical precision $<$ 5\% (Pant et al., 2020b).

\section{Human and Health Risk Assessment Water Quality Index (WQI)}

The WQI is one of the useful tools that represent the overall water quality at a certain place and time based on TEs concentrations (Wu et al., 2018). The weightings (Wi) are allotted according to the relative significance of water quality parameters in the overall quality of drinking water (US-EPA, 
Nep J Environ Sci (2021), 9(1), 29-40

https://doi.org/10.3126/njes.v9i1.36603

1989; Li and Zhang, 2010; Pant et al., 2021b). The water quality parameters with given Wi were used in WQI calculation, and the lowest ranking was given for $\mathrm{Zn}$, as it possessing insignificant health effects, whereas the highest ranking was provided for $\mathrm{Pb}, \mathrm{Cd}$, and $\mathrm{Cr}$ (Xiao et al., 2014). In this study, the WQI for only ten elements were calculated due to the unavailability of other elements' drinking water standards. WQI was obtained from the relation:

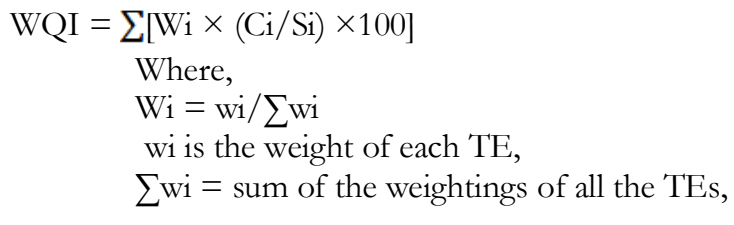

$\mathrm{Ci}=$ concentration of each TE in each water sample, $\mathrm{Si}=$ World Health Organization Guidelines for drinking water for each TE.

For this study, WHO drinking water quality guidelines were taken as reference for each TE, and their weights (Wi) were assigned using the values from Tripathee et al. (2016). The computed WQI values were classified into five different categories (Acharya et al., 2020): excellent (WQI < 50), good $(\mathrm{WQI}=50-100)$, poor $(\mathrm{WQI}=100-200)$, very poor (WQI $=200-300$ ), and unsuitable for drinking purpose (WQI > 300).

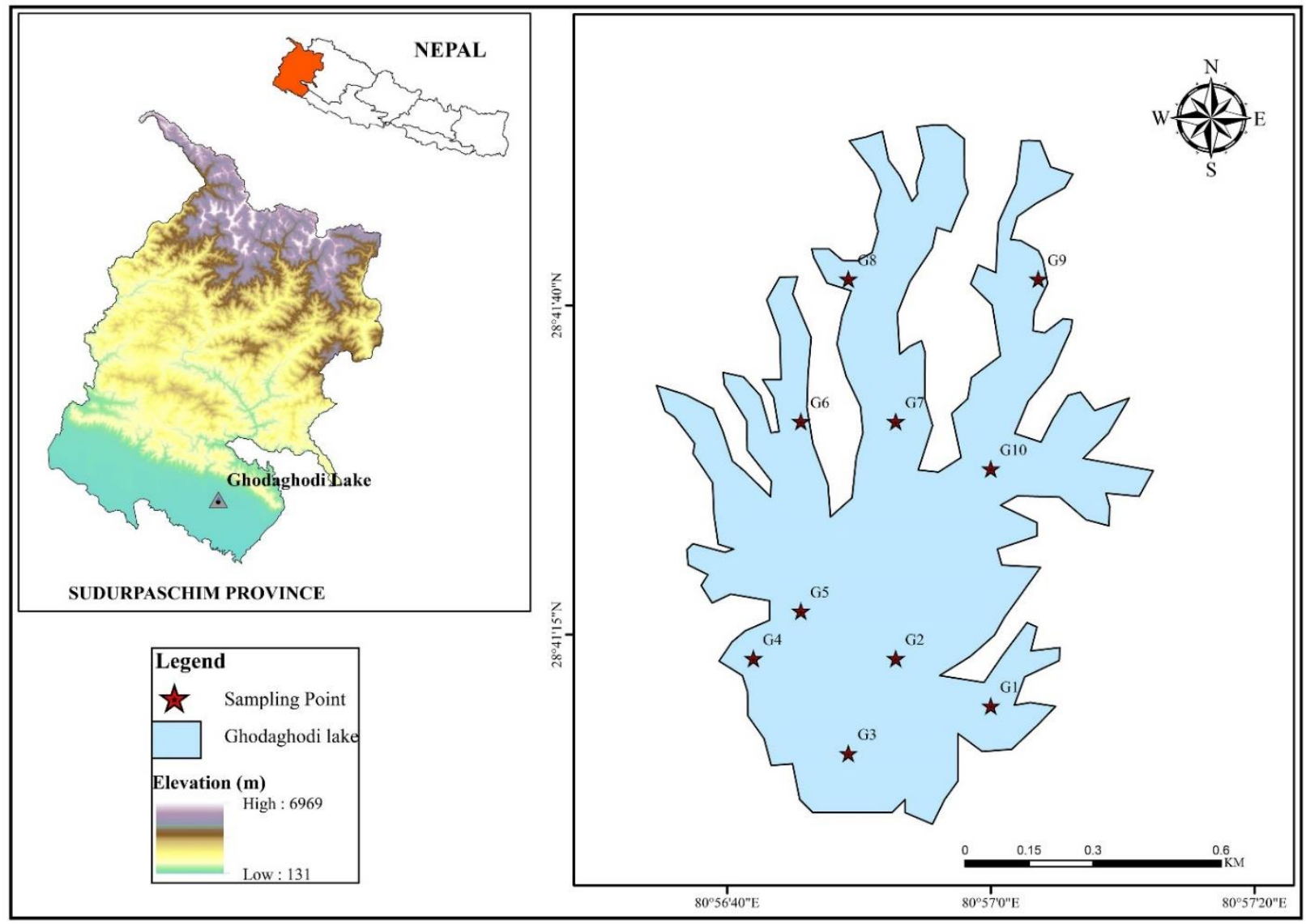

Figure 1 Sampling locations in the Ghodaghodi Lake, Sudurpaschim Province, Nepal

\section{Health Risk Assessment}

Health risk assessment models are used to quantify the potential risk of TEs to people (Wu et al., 2009). The toxicity caused by the TEs present in the lake in terms of hazard quotient (HQ) is obtained from the relation:

$$
H Q=\frac{A D D}{R f D}
$$

Where, HQ is the numerical estimation of the toxicity potential imposed by a single TE within a single route of exposure, ADD is the average daily dose (Tripathee et al., 
2016), and RfD = reference dose of the contaminant for noncarcinogenic risk $(\mathrm{mg} / \mathrm{kg} /$ day) obtained from (US EPA, 2010).

Then hazard index (HI) was calculated to indicate its overall non-carcinogenic risk ( $\mathrm{Li}$ and Zhang, 2010), for which the non-carcinogenic HQs through ingestion and dermal adsorption pathways for each TE were summed and presented as:

$$
\mathrm{HI}_{\text {ing } / \text { derm }}=H \mathrm{Q}_{\text {ing } / \text { derm }}
$$

The human population has exposure to the TEs present in water bodies via ingestion, inhalation, and dermal absorption; however, direct ingestion and dermal absorption are the most common ways. So, the exposure dose for these two main pathways was calculated as follows:

$$
\begin{gathered}
A D D \text { ingestion }=\frac{C w \times I R \times E F \times E D}{B W \times A T} \\
A D D \text { dermal }=\frac{C w \times S A \times K p \times E T \times E F \times E D \times 10^{-3}}{B W \times A T}
\end{gathered}
$$

Where,

$\mathrm{ADD}_{\text {ingestion }}=$ average daily dose from ingestion $(\mu \mathrm{g} / \mathrm{kg} /$ day $)$, $\mathrm{ADD}_{\text {dermal }}=$ average daily dose from dermal $(\mu \mathrm{g} / \mathrm{kg} / \mathrm{day}), \mathrm{Cw}$ $=$ average concentration of TEs in water $(\mu \mathrm{g} / \mathrm{L})$, IR = ingestion rate, 2 and $0.64 \mathrm{~L} /$ day for adults and children, respectively, $\mathrm{EF}=$ exposure frequency $(350$ days $/$ year assuming that the local people spend remaining 15 days away from the site), $\mathrm{ED}=$ exposure duration $(30$ years and 6 years for adults and children, respectively), BW = average body weight (assumed that the bodyweight is $70 \mathrm{~kg}$ and $15 \mathrm{~kg}$ for adults and children, respectively), AT = average time (in days), $(\mathrm{ED} \times 365$ days $), \mathrm{SA}=$ exposed skin area, $\left(18,000 \mathrm{~cm}^{2}\right.$ for adults and $6,600 \mathrm{~cm}^{2}$ for children), $\mathrm{Kp}=$ skin permeability coefficient in water $(\mathrm{cm} / \mathrm{h}), \mathrm{ET}=$ exposure time spent in bathing and shower ( 0.58 and $1 \mathrm{~h} /$ day for adults and children, respectively). These values were obtained from the reference of Tripathee et al., (2016).

The local people widely use the water from the Ghodaghodi Lake complex for drinking and other domestic purposes. Importantly, the lake is one of the most important religious sites and thousands of pilgrims consider the lake water as a holy one and use it as Jal (holy water). Meanwhile, the shallow ground water is widely used for drinking purposes in the vicinity of the lake area where the lake water acts as a recharge zone for about 75,000 people from 13,174 households in the lakeshade (Lamsal et al., 2014).

\section{Statistical analyses}

The multivariate statistical techniques were used for evaluation and interpretation of the TEs concentration and to identify the major sources of TEs in the lake. Hierarchical agglomerative cluster analysis (CA) was applied to assess the variability of the TEs and grouping of similar sampling sites based on TEs concentration. Additionally, in order to assess the potential association, Spearman's rank correlation coefficient was applied. For the identification of major sources of TEs, PCA with varimax rotation was performed (Pant et al., 2020b).

\section{Results and Discussion \\ General hydrochemistry of TEs}

The statistical summary of dissolved TEs in the surface water of Ghodaghodi Lake is presented in Table 1. Based on the mean concentration of the TEs present in the lake water, three major categories were identified: (i) concentrations $>10 \mu \mathrm{g} / \mathrm{L}$ ( $\mathrm{Sr}$ and $\mathrm{Ba}$ ), (ii) concentrations between 1 - $10 \mu \mathrm{g} / \mathrm{L}$ (Sc, Cu, As, $\mathrm{Rb}$ and $\mathrm{Zn}$ ), and (iii) concentrations $<1 \mu \mathrm{g} / \mathrm{L}(\mathrm{Li}, \mathrm{Ti}, \mathrm{V}$, Cr, Mn, Co, Ni, Y, Cd, Cs, Tl, and Pb) (Fig. 2 and Table 1). The higher concentrations of $\mathrm{Sr}$ and $\mathrm{Ba}$ were detected in the lake, which could be attributed to the underlying geology and lake sediments. In addition, the results confirmed from the fact that $\mathrm{Sr}$ and $\mathrm{Ba}$ both belong to group IIA of the periodic table and thus contributed from the same sources. Furthermore, the concentration of the $3 \mathrm{~d}$ elements such as Sc, $\mathrm{Cu}$, and $\mathrm{Zn}$ associated with other TEs such as $\mathrm{Rb}$ and $\mathrm{As}$ were found with their moderate concentrations. While $\mathrm{Li}, \mathrm{Ti}, \mathrm{V}, \mathrm{Cr}$, $\mathrm{Mn}, \mathrm{Co}, \mathrm{Ni}, \mathrm{Y}, \mathrm{Cd}, \mathrm{Cs}, \mathrm{Tl}$, and $\mathrm{Pb}$ in the lake water samples have relatively lower concentrations, indicating the low anthropic contamination in the lake. The measured TEs were compared with the drinking water guidelines established by the WHO and US EPA (Table 1). The concentrations of all TEs in the present study were within the permissible limit of standard guidelines and mostly less than the global average of freshwater ecosystems (Gaillardet et al., 2014).

Some of the elements showed relatively higher standard deviation in this study (Table 1). The elements such as Rb; and $\mathrm{Ba}$ and $\mathrm{Sr}$ are the crustal elements (alkali and alkaline earth metals) and they have naturally high concentrations in the lake basin whereas the lake water is impacted by the activities of visitors specially the pilgrims so the concentration of $\mathrm{Cu}$ and $\mathrm{Zn}$ could be fluctuated. So, higher standard deviation of those elements could be due to the geogenic and anthropic factors.

\section{Correlation matrices (CM)}

The CM can be applied to indicate the origin, controlling mechanisms and transport of the TEs. It also shows potential associations among various TEs (Pant et al., 2020b). Spearman's rank correlation coefficient showed that Ti-Sc; Co-Sc-Ti; Ni-Cr; As-Ti-Mn; Sr-Sc-Ti-Co-Cu; Cd-Cu; Ba-ScTi-Co-Ni-Sr; Pb-Ba have a strong positive correlation $(\mathrm{p}<$ 0.01 ), indicating that the TEs have similar sources (Table 2). The strong correlation $(\mathrm{r}>0.75)$ indicates similar sources including geologic, pedogenic, and anthropic processes $(\mathrm{Li}$ and Zhang 2010b). Similarly, Cu-Sc-Ti; Tl-Li; Cs-Cd; Pb-Co; Pb-Sr exhibited moderate positive correlation $(\mathrm{r}=0.5-0.75$; $\mathrm{p}<$ 0.05; Table 2) in the lake indicating that these elements were derived from mixed but similar sources whereas $\mathrm{Pb}$ has a moderate negative correlation with $\mathrm{Zn}(\mathrm{p}<0.05)$ exhibiting their different origin. Also, In Table 2, some TEs were found significant negative correlation, it indicates that they may have 
Nep J Environ Sci (2021), 9(1), 29-40

https://doi.org/10.3126/njes.v9i1.36603

different sources of origin. Most of the aforementioned association highlighted that the TEs concentration is primarily derived from natural geogenic and pedogenic sources with the minor signature of anthropic contribution. Prior studies on the southern slope of central Himalayan freshwater lakes have also suggested mostly similar associations of the TEs (Bhatta et al., 2020; Thapa \& Saund, 2013).

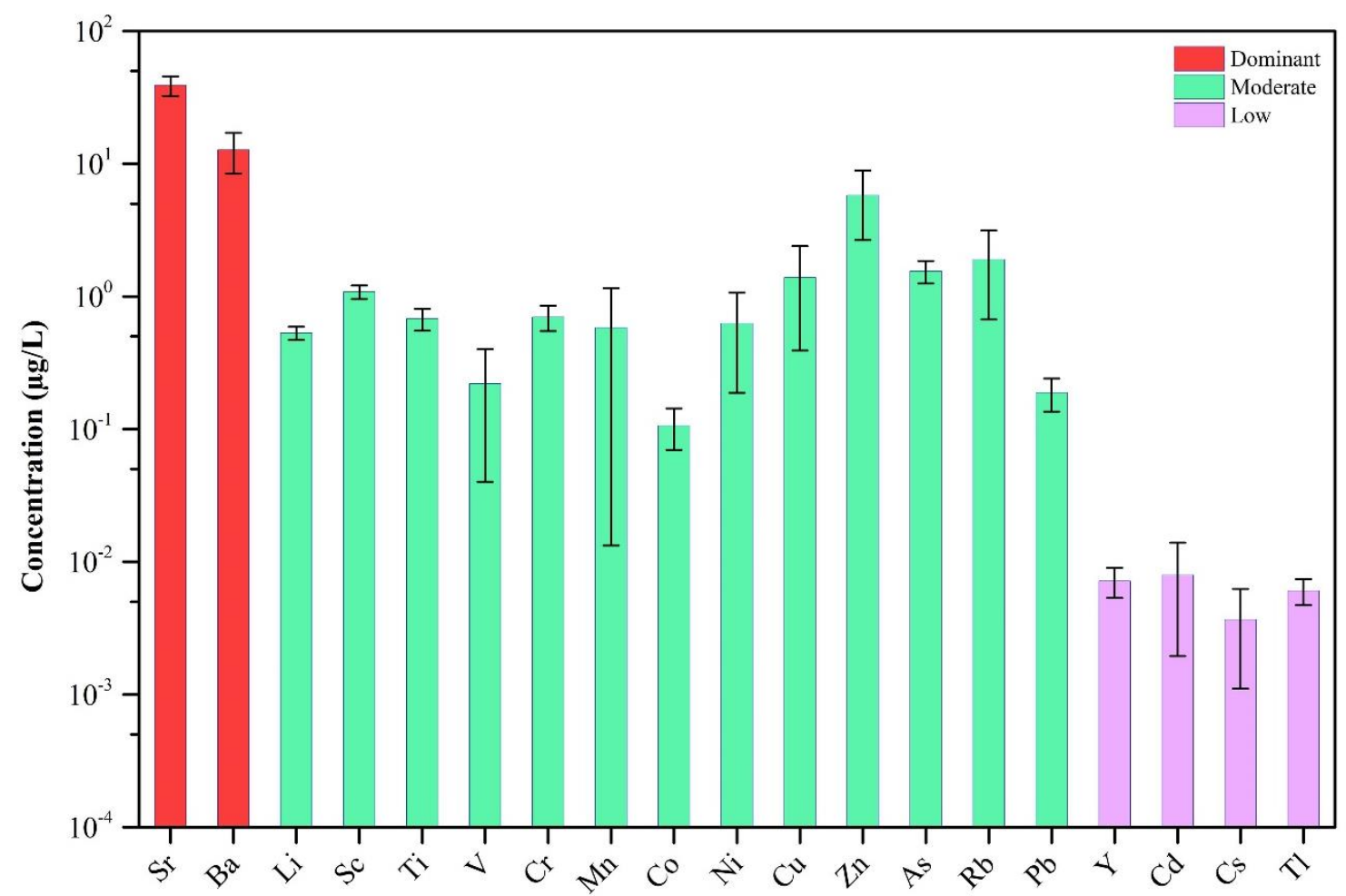

Figure 2 Mean concentrations of trace elements (TEs) in the Ghodaghodi Lake, Sudurpaschim Province, Nepal

\section{Cluster analysis (CA)}

The dendrogram resulting from ward's method showed three major clusters that were Cluster 1 (sites 3, 7, 8, 9, and 10), Cluster 2 (sites 1, 2, 4, and 5), and Cluster 3 (site 6) (Fig. 3). Cluster 1 was relatively less contaminated with the dominancy of $\mathrm{Ba}$ as a crustal element. However, Cluster 2 was characterized by the dominancy of $\mathrm{Ni}, \mathrm{Zn}$, and $\mathrm{Rb}$ elements indicating major anthropic activities such as chemical fertilizers, pesticides, and pilgrims' activities in the lake complex. Moreover, Cluster 3 showed the characteristic features of pedogenic contamination of $\mathrm{Mn}$ and As, primarily derived from the process of soil formation in the lake complex. In addition, the ongoing developmental activities such as road construction may also be responsible for the elevated concentration of $\mathrm{As}$ and $\mathrm{Mn}$ in the lake. Thus, from the CA, it can be determined that the lake Ghodaghodi is relatively less polluted by anthropic sources where the geogenic and pedogenic activities are the major sources of TEs.

\section{Principal component analysis (PCA)}

The PCA is the linear combination of the original variables and explains the variance of a large set of original variables using a smaller set of newly independent variables. In this study, the cumulative variance with $93.10 \%$ and values $>1$ successfully identified the four principal components (PCs) via PCA of the varimax rotation process (Fig. 4, Table 3). Meanwhile, the components loadings with $>0.75$, and 0.50 0.75 , respectively, were discussed as strong and moderate associations of the TEs (Pant et al., 2020b). PC1 explained that $38.87 \%$ of the total variance had strong positive loadings on $\mathrm{Ba}, \mathrm{Co}, \mathrm{Cu}, \mathrm{Sc}, \mathrm{Sr}$, and Ti. Furthermore, it exhibited moderate positive loadings on $\mathrm{Pb}$, and negative loadings on $\mathrm{Y}$. $\mathrm{Sr}$ and $\mathrm{Ba}$ are group IIA elements and found in the earth crust, and thus the other elements associated with this group are also contributed primarily from the geogenic source. PC2 explained $27.94 \%$ of total variance with strong positive loadings on $\mathrm{Zn}, \mathrm{Rb}, \mathrm{Cd}$, and $\mathrm{Cs}$ and moderate positive loadings on $\mathrm{Cr}$ and $\mathrm{Ni}$. Elements of this group included IA and IIB, and they are associated with the mixed sources of origin. We ascribed that these elements are influenced by the signature of anthropic inputs such as chemical fertilizers and religious activities around the lake. PC3 explained $13.68 \%$ of total variance with strong positive loadings on $\mathrm{Li}$ and $\mathrm{Tl}$ and moderate positive loadings on $\mathrm{Cr}$. Furthermore, this group has strong negative loadings on $\mathrm{V}$ and moderate negative loadings on Co. The characteristics of this group ascribed that the elements were mainly contributed from natural sources. 
Nep J Environ Sci (2021), 9(1), 29-40

https://doi.org/10.3126/njes.v9i1.36603

Table 1 Concentration of the trace elements (TEs) in the Ghodaghodi Lake (unit in $\mu \mathrm{g} / \mathrm{L}$ )

\begin{tabular}{|c|c|c|c|c|c|c|}
\hline \multirow{2}{*}{ Elements } & \multirow{2}{*}{ Min } & \multirow{2}{*}{ Max } & \multirow{2}{*}{ Mean } & \multirow{2}{*}{$\mathrm{SD}$} & \multicolumn{2}{|c|}{ Drinking-Water Guidelines } \\
\hline & & & & & WHO & US EPA \\
\hline $\mathrm{Li}$ & 0.46 & 0.64 & 0.53 & 0.06 & - & - \\
\hline $\mathrm{Ti}$ & 0.48 & 0.86 & 0.68 & 0.13 & - & - \\
\hline $\mathrm{V}$ & 0.00 & 0.48 & 0.22 & 0.18 & - & - \\
\hline Mn & 0.32 & 2.17 & 0.58 & 0.57 & 400 & - \\
\hline Co & 0.07 & 0.17 & 0.11 & 0.04 & 50 & - \\
\hline $\mathrm{Ni}$ & 0.14 & 1.72 & 0.63 & 0.44 & 70 & - \\
\hline $\mathrm{Cu}$ & 0.36 & 3.20 & 1.39 & 1.00 & 2000 & 1300 \\
\hline Sr & 26.25 & 49.72 & 39.09 & 6.58 & - & - \\
\hline $\mathrm{Y}$ & 0.00 & 0.01 & 0.01 & 0.00 & - & - \\
\hline $\mathrm{Cd}$ & 0.00 & 0.02 & 0.01 & 0.01 & 3 & 5 \\
\hline Cs & 0.00 & 0.01 & 0.00 & 0.00 & - & - \\
\hline $\mathrm{Ba}$ & 3.97 & 18.86 & 12.78 & 4.30 & 700 & - \\
\hline $\mathrm{Tl}$ & 0.00 & 0.01 & 0.01 & 0.00 & - & - \\
\hline $\mathrm{Pb}$ & 0.10 & 0.25 & 0.19 & 0.05 & 10 & 10 \\
\hline
\end{tabular}

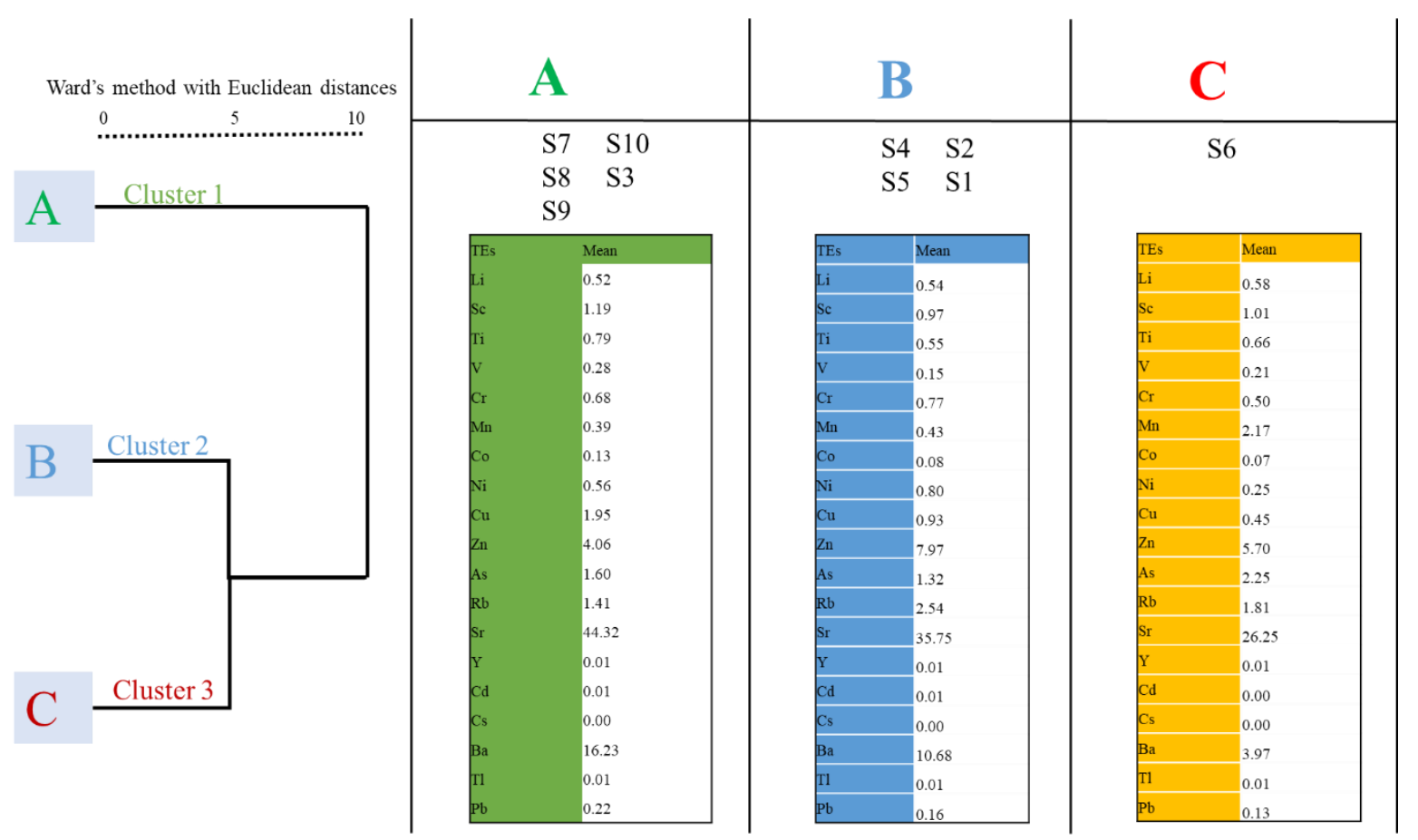

Figure 3 Dendrogram showing the clustering of sampling locations based on trace elements (TEs) in the Ghodaghodi Lake, Sudurpaschim Province, Nepal 
Table 2 Correlation matrices of the trace elements (TEs) in Ghodaghodi Lake, Sudurpaschim Province, Nepal

\begin{tabular}{|c|c|c|c|c|c|c|c|c|c|c|c|c|c|c|c|c|c|c|c|}
\hline Elements & $\mathrm{Li}$ & Sc & $\mathrm{Ti}$ & $\mathrm{v}$ & $\mathrm{Cr}$ & Mn & Co & $\mathrm{Ni}$ & $\mathrm{Cu}$ & $\mathrm{Zn}$ & As & $\mathbf{R b}$ & $\mathrm{Sr}$ & $\mathbf{Y}$ & $\mathrm{Cd}$ & Cs & $\mathrm{Ba}$ & $\mathrm{T} 1$ & $\mathrm{~Pb}$ \\
\hline $\mathrm{Li}$ & 1.00 & & & & & & & & & & & & & & & & & & \\
\hline Sc & -0.43 & 1.00 & & & & & & & & & & & & & & & & & \\
\hline $\mathrm{Ti}$ & -0.43 & $0.95^{* *}$ & 1.00 & & & & & & & & & & & & & & & & \\
\hline V & -0.57 & 0.28 & 0.35 & 1.00 & & & & & & & & & & & & & & & \\
\hline $\mathrm{Cr}$ & 0.59 & -0.15 & -0.37 & -0.53 & 1.00 & & & & & & & & & & & & & & \\
\hline $\mathrm{Mn}$ & 0.16 & 0.29 & 0.51 & 0.15 & -0.42 & 1.00 & & & & & & & & & & & & & \\
\hline Co & -0.61 & $0.90^{* *}$ & $0.89 * *$ & 0.30 & -0.20 & 0.16 & 1.00 & & & & & & & & & & & & \\
\hline $\mathrm{Ni}$ & 0.60 & -0.08 & -0.18 & -0.38 & $0.83^{* *}$ & -0.24 & -0.08 & 1.00 & & & & & & & & & & & \\
\hline $\mathrm{Cu}$ & -0.07 & $0.66^{*}$ & $0.69 *$ & 0.27 & 0.07 & 0.45 & 0.63 & 0.23 & 1.00 & & & & & & & & & & \\
\hline $\mathrm{Zn}$ & 0.47 & -0.40 & -0.53 & -0.16 & 0.42 & -0.07 & -0.63 & 0.02 & -0.12 & 1.00 & & & & & & & & & \\
\hline As & 0.07 & 0.62 & $0.75^{*}$ & 0.29 & -0.38 & $0.84 * *$ & 0.38 & -0.23 & 0.52 & -0.13 & 1.00 & & & & & & & & \\
\hline $\mathrm{Rb}$ & 0.53 & -0.24 & -0.27 & -0.10 & 0.39 & 0.21 & -0.38 & 0.20 & 0.38 & $0.77 * *$ & 0.08 & 1.00 & & & & & & & \\
\hline $\mathrm{Sr}$ & -0.21 & $0.81 * *$ & $0.79 * *$ & 0.13 & 0.12 & 0.24 & $0.87 * *$ & 0.28 & $0.86 * *$ & -0.44 & 0.41 & -0.03 & 1.00 & & & & & & \\
\hline Y & 0.52 & -0.52 & -0.52 & -0.29 & 0.41 & -0.18 & -0.47 & 0.52 & -0.52 & -0.06 & -0.29 & -0.17 & -0.41 & 1.00 & & & & & \\
\hline $\mathrm{Cd}$ & -0.07 & 0.38 & 0.31 & 0.43 & 0.25 & 0.09 & 0.35 & 0.26 & $0.82 * *$ & 0.25 & 0.17 & 0.55 & 0.60 & -0.50 & 1.00 & & & & \\
\hline Cs & -0.34 & 0.34 & 0.27 & 0.57 & -0.04 & -0.19 & 0.31 & 0.08 & 0.57 & 0.04 & 0.04 & 0.27 & 0.34 & -0.51 & $0.73 *$ & 1.00 & & & \\
\hline $\mathrm{Ba}$ & -0.32 & $0.77^{* *}$ & $0.78 * *$ & 0.13 & -0.02 & 0.19 & $0.89 * *$ & 0.15 & $0.75^{*}$ & -0.59 & 0.35 & -0.16 & $0.96 * *$ & -0.41 & 0.45 & 0.27 & 1.00 & & \\
\hline $\mathrm{Tl}$ & $0.65 *$ & -0.57 & -0.42 & -0.34 & 0.19 & 0.19 & -0.51 & 0.38 & -0.19 & 0.04 & -0.11 & 0.11 & -0.19 & 0.51 & -0.16 & -0.52 & -0.19 & 1.00 & \\
\hline $\mathrm{Pb}$ & -0.35 & 0.47 & 0.58 & 0.03 & -0.26 & 0.22 & $0.71 *$ & -0.13 & 0.43 & $-0.66 *$ & 0.24 & -0.23 & $0.68 *$ & -0.29 & 0.08 & -0.04 & $0.84 * *$ & -0.08 & 1.00 \\
\hline
\end{tabular}

* Correlation is significant at the 0.05 level (2-tailed).

** Correlation is significant at the 0.01 level (2-tailed).

PC4 showed $12.61 \%$ of the total variance with strong positive loadings on Mn and As, and moderate negative loadings on $\mathrm{Cr}$ and $\mathrm{Y}$. The grouping of these elements indicated that they were mainly originated from pedogenic processes. The PCA analysis demonstrated a minor anthropic signature for the contribution of TEs, and elemental composition was mostly governed by natural factors in the Ghodaghodi Lake. However, increasing anthropic activities around the lake could be one of the significant factors contaminating the water of the lake in the future. 

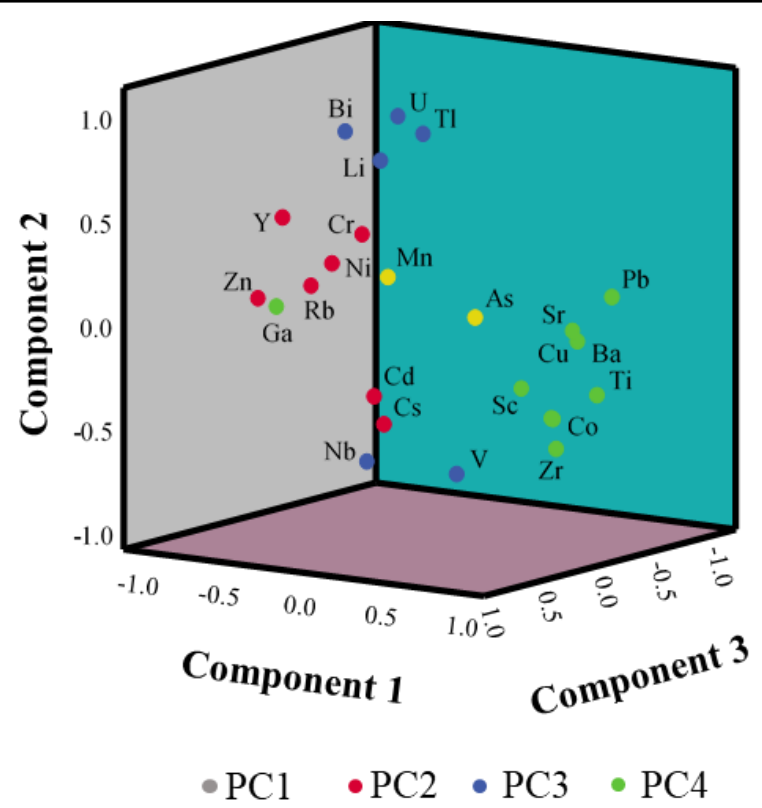

Figure 4 Factor loading plot of the PCA for trace elements (TEs) in the Ghodaghodi Lake, Sudurpaschim, Nepal

Table 3 Rotated component matrix of the trace elements (TEs) composition in the Ghodaghodi Lake, Sudurpaschim Province, Nepal

\begin{tabular}{|c|c|c|c|c|}
\hline & PC1 & PC2 & PC3 & PC4 \\
\hline $\mathrm{Li}$ & -0.08 & 0.34 & 0.91 & 0.21 \\
\hline $\mathrm{Sc}$ & 0.86 & 0.10 & -0.18 & 0.16 \\
\hline $\mathrm{Ti}$ & 0.88 & -0.22 & -0.24 & 0.32 \\
\hline V & 0.29 & 0.24 & -0.77 & 0.25 \\
\hline $\mathrm{Cr}$ & 0.01 & 0.57 & 0.59 & -0.53 \\
\hline $\mathrm{Mn}$ & -0.37 & -0.12 & 0.16 & 0.90 \\
\hline Co & 0.78 & 0.02 & -0.57 & 0.03 \\
\hline $\mathrm{Ni}$ & -0.12 & 0.69 & 0.41 & -0.39 \\
\hline $\mathrm{Cu}$ & 0.83 & 0.45 & -0.13 & 0.12 \\
\hline $\mathrm{Zn}$ & -0.49 & 0.80 & 0.21 & -0.17 \\
\hline As & 0.17 & -0.13 & 0.12 & 0.96 \\
\hline $\mathrm{Rb}$ & -0.15 & 0.90 & 0.28 & 0.00 \\
\hline Sr & 0.92 & 0.04 & 0.08 & -0.38 \\
\hline $\mathrm{Y}$ & -0.57 & 0.46 & 0.45 & -0.51 \\
\hline $\mathrm{Cd}$ & 0.27 & 0.93 & -0.18 & -0.14 \\
\hline Cs & 0.29 & 0.88 & -0.33 & -0.04 \\
\hline $\mathrm{Ba}$ & 0.91 & -0.02 & -0.01 & -0.42 \\
\hline $\mathrm{Tl}$ & -0.10 & -0.01 & 0.85 & 0.40 \\
\hline $\mathrm{Pb}$ & 0.74 & -0.49 & -0.09 & -0.12 \\
\hline Eigenvalue & 7.38 & 5.31 & 2.60 & 2.40 \\
\hline Variance (\%) & 38.87 & 27.94 & 13.68 & 12.61 \\
\hline Cumulative $(\%)$ & 38.87 & 66.81 & 80.49 & 93.10 \\
\hline
\end{tabular}


Nep J Environ Sci (2021), 9(1), 29-40

https://doi.org/10.3126/njes.v9i1.36603

\section{Water quality index (WQI)}

The WQI of the Ghodaghodi Lake based on the measured TEs is presented in Table 4. As the WHO guideline values for other elements were unavailable, only ten TEs were used to calculate the WQI of Ghodaghodi Lake. In this study, the total weight $\left(\sum \mathrm{Wi}\right)$ of TEs was 32. In comparison with the previous studies of freshwater lakes of Nepal, Himalaya, the total weight assigned for this study is relatively low (Rupakheti et al., 2017). The WQI for Ghodaghodi Lake was observed to be 10.08 that belonged in the excellent category (WQI $<50$ ). It also indicates that the lake water is potable and could be used for drinking purposes from the perspective of measured elements. Importantly, the results are solely based on TEs and other important analysis such as microbial activities are not included in this study. The WQI of the lake was relatively lower as compared to the other Himalayan lakes such as Phewa (159.2) and Gosainkunda (11.5) (Rupakheti et al., 2017). It indicated that Lake Ghodaghodi is relatively pristine compared to the aforementioned lakes; however, the weight assigned and incorporation of $\mathrm{Hg}$ could also be responsible for the different results of the WQI in the earlier studies.

Table 4 Water Quality Index (WQI) of the Ghodaghodi Lake, Sudurpaschim Province, Nepal

\begin{tabular}{llllll}
\hline Elements & Weight of elements & $\mathrm{Wi}$ & $\mathrm{Ci}$ & $\mathrm{Si}$ & $\mathrm{Ci} / \mathrm{Si}$ \\
\hline $\mathrm{Cd}$ & 5.000 & 0.156 & 0.010 & 3 & 0.003 \\
$\mathrm{Cr}$ & 5.000 & 0.156 & 0.700 & 50 & 0.014 \\
$\mathrm{Cu}$ & 2.000 & 0.063 & 1.390 & 2000 & 0.0006 \\
$\mathrm{~Pb}$ & 5.000 & 0.156 & 0.190 & 10 & 0.019 \\
$\mathrm{Mn}$ & 5.000 & 0.156 & 0.580 & 400 & 0.001 \\
$\mathrm{As}$ & 5.000 & 0.156 & 1.550 & 50 & 0.031 \\
$\mathrm{Zn}$ & 1.000 & 0.031 & 5.790 & 3000 & 0.001 \\
$\mathrm{Ni}$ & 1.000 & 0.031 & 0.630 & 70 & 0.009 \\
$\mathrm{Co}$ & 1.000 & 0.031 & 0.110 & 50 & 0.002 \\
$\mathrm{Ba}$ & 2.000 & 0.063 & 12.780 & 700 & 0.018 \\
\hline Total & 32.000 & 1.000 & & & 0.100 \\
& & & & & $\mathbf{W Q I}=\mathbf{1 0 . 0 8}$ \\
\hline
\end{tabular}

\section{Hazard risk assessment (HRA)}

The estimated HQ values of the measured TEs through ingestion and dermal absorption pathway for both adults and children are listed in Table 5. The HQ values $>1$ indicated that the residents are exposed to health risks from using the lake water, whereas HQ $<1$ indicated minimal risk (Dai et al., 2016). In this study, the HQ ingestion and HQ dermal values for all elements were $<1$, which indicated the minimal health effects on humans for both adults and children. As compared to adults, higher HQ ingestion and HQ dermal values for children were observed, suggesting that children are more sensitive when exposed to TEs in water, as similar to the previous study (Li \& Zhang, 2010). So, the children should be given special attention and should be less exposed to these TEs. Overall, the $\mathrm{HI}$ for $\mathrm{As}, \mathrm{Co}$, and $\mathrm{Cr}$ was higher compared to other elements for both adults and children, which may contribute more risk to human health. $\mathrm{Zn}$ presented little health threat to residents despite its high concentration in the water as it has low toxicity. Co indicated a high risk to human health despite its low concentration in the water due to its very low reference dose (RfD). Adverse effects for Co included allergic dermatitis, and other TEs might affect the nervous, hemopoietic, cardiovascular, and endocrine systems (Fang et al., 2014). From these risk evaluations, it could be suggested that currently there is a low risk due to TEs to the inhabitants in the vicinity of the lakes. However, the sources of the TEs, their concentrations and potential health risks including longrange transport of the pollutants are assessed in the few lakes in the region (Pant et al., 2020a; Pant et al., 2021b; Rupakheti et al., 2017; Sharma et al., 2014; Tripathee et al., 2016). Thus, this study could be useful for the government authorities, decision-makers and other concerned stakeholders for the sustainable management of the Ramsar listed lakes in the Himalaya. 
Nep J Environ Sci (2021), 9(1), 29-40

https://doi.org/10.3126/njes.v9i1.36603

Table 5 Hazard Quotient for adults and children for each trace element (TEs) in the Ghodaghodi Lake, Nepal

\begin{tabular}{clllllllll}
\hline & & & & \multicolumn{2}{c}{ Adult } & & \multicolumn{3}{c}{ Children } \\
\cline { 5 - 9 } TEs & $\mathrm{CW}$ & RfD $_{\text {Ingestion }}$ & RfD Dermal & HQ Ingestion & HQ Dermal & HI & HQ Ingestion & HQ Dermal & HI \\
\hline $\mathrm{As}$ & 1.55 & 0.3 & 0.123 & $1.48 \times 10^{-1}$ & $1.88 \times 10^{-3}$ & $1.49 \times 10^{-1}$ & $2.20 \times 10^{-1}$ & $5.54 \times 10^{-3}$ & $2.26 \times 10^{-1}$ \\
$\mathrm{Ba}$ & 0.01 & 200 & 14 & $1.43 \times 10^{-6}$ & $1.07 \times 10^{-7}$ & $1.54 \times 10^{-6}$ & $2.13 \times 10^{-6}$ & $3.14 \times 10^{-7}$ & $2.45 \times 10^{-6}$ \\
$\mathrm{Cd}$ & 0.01 & 0.5 & 0.025 & $5.71 \times 10^{-4}$ & $5.97 \times 10^{-5}$ & $6.31 \times 10^{-4}$ & $8.53 \times 10^{-4}$ & $1.76 \times 10^{-4}$ & $1.03 \times 10^{-3}$ \\
$\mathrm{Co}$ & 0.11 & 0.3 & 0.06 & $1.05 \times 10^{-2}$ & $1.09 \times 10^{-4}$ & $1.06 \times 10^{-2}$ & $1.56 \times 10^{-2}$ & $3.23 \times 10^{-4}$ & $1.60 \times 10^{-2}$ \\
$\mathrm{Cr}$ & 0.70 & 3 & 0.075 & $6.67 \times 10^{-3}$ & $1.39 \times 10^{-3}$ & $8.06 \times 10^{-3}$ & $9.96 \times 10^{-3}$ & $4.11 \times 10^{-3}$ & $1.41 \times 10^{-2}$ \\
$\mathrm{Cu}$ & 1.39 & 40 & 8 & $9.93 \times 10^{-4}$ & $2.59 \times 10^{-5}$ & $1.02 \times 10^{-3}$ & $1.48 \times 10^{-3}$ & $7.65 \times 10^{-5}$ & $1.56 \times 10^{-3}$ \\
$\mathrm{Mn}$ & 0.58 & 24 & 0.96 & $6.90 \times 10^{-4}$ & $9.01 \times 10^{-5}$ & $7.81 \times 10^{-4}$ & $1.03 \times 10^{-3}$ & $2.66 \times 10^{-4}$ & $1.30 \times 10^{-3}$ \\
$\mathrm{Ni}$ & 0.63 & 20 & 0.8 & $9.00 \times 10^{-4}$ & $2.35 \times 10^{-5}$ & $9.24 \times 10^{-4}$ & $1.34 \times 10^{-3}$ & $6.93 \times 10^{-5}$ & $1.41 \times 10^{-3}$ \\
$\mathrm{~Pb}$ & 0.19 & 1.4 & 0.42 & $3.88 \times 10^{-3}$ & $6.75 \times 10^{-6}$ & $3.88 \times 10^{-3}$ & $5.79 \times 10^{-3}$ & $1.99 \times 10^{-5}$ & $5.81 \times 10^{-3}$ \\
$\mathrm{Zn}$ & 5.79 & 300 & 60 & $5.51 \times 10^{-4}$ & $8.64 \times 10^{-6}$ & $5.60 \times 10^{-4}$ & $8.23 \times 10^{-4}$ & $2.55 \times 10^{-5}$ & $8.49 \times 10^{-4}$ \\
\hline
\end{tabular}

\section{Conclusion}

This study was conducted to investigate the sources and potential health risks of the trace elements (TEs) of the Ghodaghodi Lake complex in Sudurpaschim Province, Nepal. Based on the mean concentrations of the TEs in the lake there are three major groups: (i) $\mathrm{Sr}$ and $\mathrm{Ba}$ (concentrations $>10$ $\mu \mathrm{g} / \mathrm{L}$ ); (ii) Sc, $\mathrm{Cu}, \mathrm{As}, \mathrm{Rb}$, and $\mathrm{Zn}$ (concentrations between 1 $10 \mu \mathrm{g} / \mathrm{L}$ ); and (iii) Li, Ti, V, Cr, Mn, Co, Ni, Y, Cd, Cs, Tl and $\mathrm{Pb}$ (concentrations of $<1 \mu \mathrm{g} / \mathrm{L}$ ). The concentrations of all the TEs are under the permissible level compared with the drinking water guidelines established by WHO and US EPA. The distribution of TEs exhibited that $\mathrm{Sr}, \mathrm{Ba}, \mathrm{Zn}, \mathrm{Cu}, \mathrm{As}, \mathrm{Sc}$, and $\mathrm{Rb}$; and $\mathrm{Cs}, \mathrm{Y}, \mathrm{Tl}, \mathrm{Cd}$, and $\mathrm{Co}$ are the major and minor contributors, respectively originating from geogenic, pedogenic, and anthropic sources.

The water quality index $<50$ (WQI=10.08) suggested that the water is suitable for drinking purposes on the basis of measured TEs. The health risk assessment concluded that there is minimal chance of causing a health risk to humans, which is consistent with the WQI. Furthermore, the relatively high hazard quotient value indicated that children could have a high risk as compared to adults due to the TEs contamination in water. Therefore, special attention should be given to reduce the risk in the future. Overall, this study suggested that the water quality of the Ghodaghodi Lake in terms of TEs is quite good; however, appropriate measures should be adopted to maintain the better water quality in the future. Thus, this study could be useful for the government authorities and decision-makers for the sustainable management of the Ramsar listed lake. Finally, future studies focusing on spatiotemporal variations and long-range transport of pollutants could give further insights into the water quality of the lake in the Himalayas.

Acknowledgements: The authors would like to thank Professor Dr. Zhang Fan for supporting the laboratory analysis of the trace elements samples in the Institute of Tibetan Plateau Research, Chinese Academy of Sciences, China. The authors are also grateful to Mr. Tarka Raj Joshi, Assistant Professor of Sudurpaschim University,Nepal for supporting during the sample collection. In addition, we acknowledge the Central Department of Environmental Science, Institute of Science and Technology, Tribhuvan University, Nepal for providing partial laboratory support and making a conducive environment for this research work.

Author Contributions: Conceptualization and data collection: R.R.P.; writing of the original manuscript: R.R.P., K.B.P., K.B., and G.P.; review and editing: L.B.T., Y.P.D., Y.R.B., G.R.J., and K.R. All authors have approved the final version of the manuscript.

Conflict of Interest: The authors declare no conflict of interest.

\section{References}

Acharya, A., Sharma, M.L., Bishwakarma, K., Dahal, P., Kumar, S., Adhikari, B., Neupane, S., Pokhrel, B.N., \& Pant, R.R., (2020). Chemical characteristics of the Karmanasha River water and its appropriateness for irrigational usage. Journal of Nepal Chemical Society, 41, 94-102. doi 10.3126/jncs.v41i1.30494.

Adhikari, B., Pant, R.R., Baral, U., Shrestha, S., Neupane, S., Khanal, B., Acharya, A., \& Bhattarai, H. (2020). Geochemical and multivariate assessment of water quality in the Rajarani Lake, Dhankuta, Nepal. Journal of Nepal Geological Society, 60, 37-49. doi 10.3/26/jngs.v60i0.31264.

Bhatta, R., Tuladhar, S., Regmi, D., Gurung, S., Joshi, R., Dahal, B.M., Raut, N., Kafle, K.R., Kayastha, R., Prasad, A., \& Tripathee, L. (2019). Water quality of Ghodaghodi Lake: a Ramsar site in western Nepal. In S. Gurung, B. Sitaula, R.M. Bajracharya, N. Raut, \& B.M. Dahal (Eds.), Proceedings of International Conference on Natural Resources, Agriculture and 
Nep J Environ Sci (2021), 9(1), 29-40

https://doi.org/10.3126/njes.v9i1.36603

Society in Changing Climate, (pp. 73-84). Kathmandu, Nepal.

Bishwakarma, K., Pant, R.R., Pal, K.B., Ghimire, A., Thapa, L.B., Saud, P., Joshi, S., \& Panthi, K.P. (2019). Water quality and land use/cover changes in the Phewa Watershed, Gandaki Province, Nepal. Nepal Journal of Environmental Science, 7, 31-39. doi 10.3126/njes.v7i0.34473.

Dai, H., Song, X., Huang, B., \& Xin, J. (2016). Health risks of heavy metals to the general public in Hengyang, China via consumption of rice. Human and Ecological Risk Assessment: An International Journal, 22, 1636-1650. doi 10.1080/108070 39.2016.1207156.

Dong, Z., Kang, S., Qin, X., Li, X., Qin, D., \& Ren, J. (2015). New insights into trace elements deposition in the snow packs at remote alpine glaciers in the northern Tibetan Plateau, China. Science of the Total Environment, 529, 101-113. doi 10.1016/j.scitotenv.2015.05.065.

Fang, T., Liu, G., Zhou, C., Sun, R., Chen, J., \& Wu, D. (2014). Lead in Chinese coals: Distribution, modes of occurrence, and environmental effects. Environmental Geochemistry and Health, 36, 563-581. doi 10.1007/s10653013-9581-4.

Gaillardet, J., Viers, J., \& Dupre, B. (2014). Trace elements in river waters. In K.K. Turekian (Eds.) Treatise on Geochemistry, 2nd Edition, Elsevier, Oxford, pp 195-235. doi 10.1016/B9 78-0-08-095975-7.00507-6.

Huang, X., Sillanpää, M., Gjessing, E.T., \& Vogt, R.D. (2009). Water quality in the Tibetan Plateau: Major ions and trace elements in the headwaters of four major Asian rivers. Science of the Total Environment, 407, 6242-6254. doi 10.1016/ j.scitotenv.2009.09.001.

Jehan, S., Ullah, I., Khan, S., Muhammad, S., Khattak, S.A., \& Khan, T. (2020). Evaluation of the Swat River, Northern Pakistan, water quality using multivariate statistical techniques and water quality index (WQI) model. Environmental Science and Pollution Research, 27, 38545-38558. doi 10.1007/s11356-020-09688-y.

Lamsal, P., Pant, K.P., Kumar, L., \& Atreya, K. (2014). Diversity, uses, and threats in the Ghodaghodi Lake Complex, a Ramsar Site in Western Lowland Nepal. ISRN Biodiversity, 1-12, 680102. doi 10.1155/2014/680102.

Li, S., \& Zhang, Q. (2010). Risk assessment and seasonal variations of dissolved trace elements and heavy metals in the Upper Han River, China. Journal of Hazardous Materials, 181, 1051-1058. doi 10.1016/j.jhazmat.2010.05.120.

Niraula, R. (2012). Evaluation of the limnological status of Beeshazar Lake, a Ramsar Site in Central Nepal. Journal of Water Resource and Protection, 4(5), 256-263. doi 10.4236/jwar p.2012.45028.

Pal, K.B., Bishwakarma, K., Chalaune, T.B., Upadhaya, D., Joshi, T.R., Thapa, L.B., Sharma, M.L., Joshi, S., \& Pant, R.R. (2021). Hydrochemical assessment of Jhilmila Lake, Kanchanpur, Nepal. Scientific World, 14(4), 124-131. doi 10.3 126/sw.v14i14.35023.

Pant, R.R., Bishwakarma, K., Basnet, B.B., Pal, K.B., Karki, L., Dhital, Y.P., Bhatta, Y.R., Pant, B.R., \& Thapa, L.B. (2021a). Distribution and risk appraisal of dissolved trace elements in Begnas Lake and Rupa Lake, Gandaki Province, Nepal. SN Applied Sciences, 3, 1-13. doi 10.1007/s4245202104516-5.

Pant, R.R., Bishwakarma, K., Nepal, J., Paudel, S., Chand, M.B., Qaisar, F.U.R., Pal, K.B., Thapa, L.B., \& Wang, G. (2021b). Seasonal variations and health risk assessment of trace elements in Seti River Basin, Gandaki Province, Nepal. Bulletin of Environmental Contamination and Toxicology, 1-8. doi 10.1007/s00128-021-03288-3.

Pant, R.R., Bishwakarma, K., Qaiser, F.U.R., Pathak, L., Jayaswal, G., Sapkota, B., Pal, K.B., Thapa, L.B., Koirala, M., Rijal, K., \& Maskey, R. (2021c). Imprints of COVID-19 lockdown on the surface water quality of Bagmati river basin , Nepal. Journal of Environmental Management, 289, 1-13. doi 10.1016/j.jenvman.2021.112522.

Pant, R.R., Zhang, F., Rehman, F.F., Koirala, M., Rijal, K., \& Maskey, R. (2020a). Spatiotemporal characterization of dissolved trace elements in the Gandaki River, Central Himalaya Nepal. Journal of Hazardous Materials, 389, 121913. doi 10.1016/j.jhazmat.2019.121913.

Pant, R.R., Khanal, N.B., Pal, K.B., Thapa, L.B., Galaju, R., Chaudhari, S.K., Basnet, B.B., Dhami, N., Duediev, K., \& Bishwakarma, K. (2020b). Hydrochemical characteristics and macrophytes in the Betana Lake, Eastern Nepal. Journal of Sustainable Agriculture, 3, 44-51.

Pant, R.R., Zhang, F., Rehman, F.U., Wang, G., Ye, M., Zeng, C., \& Tang, H. (2018). Spatiotemporal variations of hydrogeochemistry and its controlling factors in the Gandaki River Basin, Central Himalaya Nepal. Science of the Total Environment, 622-623, 770-782. doi. /10.1016/j.scitote nv.2017.12.063.

Rupakheti, D., Tripathee, L., Kang, S., Sharma, C.M., Paudyal, R., \& Sillanpää, M. (2017). Assessment of water quality and health risks for toxic trace elements in urban Phewa and remote Gosainkunda lakes, Nepal. Human and Ecological Risk. Assessment, 23, 959-973. doi 10.1080/10807039.2017.12921 17.

Shah, M.T., Ara, J., Muhammad, S., Khan, S., \& Tariq, S. (2012). Health risk assessment via surface water and subsurface water consumption in the mafic and ultramafic terrain, Mohmand agency, northern Pakistan. Journal of Geochemical Exploration, 118, 60-67. doi 10.1016/j.gexplo.201 2.04.008.

Sharma, C.M., Kang, S., Sillanpää, M., Li, Q., Zhang, Q., Huang, J., Tripathee, L., Sharma, S., \& Paudyal, R. (2015). Mercury and selected trace elements from a remote (Gosainkunda) and an urban (Phewa) Lake Waters of Nepal. Water, Air and Soil Pollution, 226, 1-11. doi 10.1007/s1 1270-014-2276-3.

Tripathee, L., Kang, S., Sharma, C.M., Rupakheti, D., Paudyal, R., Huang, J., \& Sillanpää, M. (2016). Preliminary health risk assessment of potentially toxic metals in surface water of the Himalayan Rivers, Nepal. Bulletin of Environmental Contamination and Toxicology, 97, 855-862. doi 10.1007/s0012

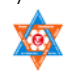


Nep J Environ Sci (2021), 9(1), 29-40

https://doi.org/10.3126/njes.v9i1.36603

8-016-1945-x.

US-EPA. (1989). Carcinogen risk assessment. Environmental Health Perspective, 81, 103-105. doi 10.1289/ehp.8981103.

WHO. (2011). Guidelines for Drinking-water Quality, Geneva Switzerland. Retrieved January 10, 2021 from <http://www.who.int/water_sanitation_health/publication s/2011/dwq_guidelines/en/>.

Wu, B., Zhao, D.Y., Jia, H.Y., Zhang, Y., Zhang, X.X., \& Cheng, S.P. (2009). Preliminary risk assessment of trace metal pollution in surface water from Yangtze River in Nanjing section, China. Bulletin of Environmental Contamination and Toxicology, 82, 405-409. doi. /10.1007/s00128-008-94973.
Wu, Z., Wang, X., Chen, Y., Cai, Y., \& Deng, J. (2018). Assessing river water quality using water quality index in Lake Taihu Basin, China. Science of the Total Environment, 612, 914-922. doi 10.1016/J.SCITOTENV.2017.08.293.

Xiao, J., Jin, Z., \& Wang, J. (2014). Geochemistry of trace elements and water quality assessment of natural water within the Tarim River Basin in the extreme arid region, NW China. Journal of Geochemical Exploration, 136, 118-126. doi 10.1016/j.gexplo.2013.10.013.

Xie, Z., Jiang, Y., Zhang, H., Wang, D., \& Qi, S. (2016). Assessing heavy metal contamination and ecological risk in Poyang Lake area, China. Environmental Earth Sciences, 75, 549. doi 10.1007/s12665-015-5240-7. 